\title{
RE-EXAMINING THE "TWIN DEFICITS” HYPOTHESIS: EVIDENCE FROM AUSTRALIA
}

\author{
Anthony J Makin \\ Paresh Kumar Narayan
}

\begin{abstract}
This paper re-examines the relationship between fiscal imbalances and net foreign borrowing. A general analytical approach is first developed which suggests that, other things equal, a rise (fall) in any advanced economy's fiscal deficit should be fully matched by a rise (fall) in its net foreign borrowing, in accordance with the so-called "twin deficits" hypothesis. In the case of Australia, one of the world's largest foreign borrower economies for its size, empirical estimation yields the novel result that Australia's consolidated budget imbalance and its foreign borrowing were approximately twinned on the basis of quarterly data for 1983-2009, when Australia's exchange rate floated and international capital mobility was high. This result is consistent with the conceptual framework and suggests that fiscal policy is likely to be ineffective as an instrument for influencing the real economy.
\end{abstract}

Acknowledgement: The authors are grateful to an anonymous reviewer for constructive comments.

Keywords fiscal imbalances, twin deficits, Australia

JEL Classification $\quad$ E62 $\cdot \mathrm{F} 32 \cdot \mathrm{H} 62$

Anthony J Makin

Griffith Business School, Griffith University, Gold Coast 4222, Australia

Telephone (+61) 7555 27084, t.makin@griffith.edu.au

Paresh Kumar Narayan

Financial Econometrics Group, School of Accounting, Economics and Finance, Deakin University, Burwood 3125 Australia

paresh.narayan@deakin.edu.au 


\section{Introduction}

A sizeable international literature on the relationship between fiscal deficits and current account imbalances suggests that for many industrial and emerging economies these two macroeconomic variables are not strongly related. Indeed, the so-called "twin deficits" hypothesis, originally proposed to explain the United States current account deficit in the 1980s and early 1990s, is generally perceived to be invalid in light of the lack of evidence

for any country of the one-for-one nexus between fiscal and external imbalances that is necessary for the hypothesis to hold.

Previous studies which have examined the impact of fiscal as well as other factors on current account behaviour (see, for instance, Chinn and Prasad 2000, Corsetti and Müller 2006, Dibooglu 1997, International Monetary Fund 2008, Kraay and Ventura 2000, Makin 2004, Nason and Rogers 2002 and Normandin 1999) reveal that the link between budget and external account imbalances in industrial and emerging economies has not always been statistically significant, and when significant, is considerably less than onefor-one. In fact, these studies show that current account deteriorations associated with larger fiscal deficits have not in the past exceeded more than forty per cent of deteriorations in fiscal imbalances. On the other hand, Kim and Roubini (2008), provide evidence that higher budget deficits in the United States have tended to lower not raise its external deficit.

This paper re-examines this important issue by first outlining a conceptual basis for linking fiscal deficits and external deficits and the net foreign borrowing associated with them. It then specifically addresses the case of Australia whose external deficit has been one of the largest by OECD standards, averaging 4.5 per cent of its GDP since capital account liberalization and the float of the Australian dollar exchange rate in the early 1980's. Australia's foreign borrowing has resulted in a net foreign debt level that exceeds 60 percent of GDP, also making it one of the world's biggest international debtors for its size due to current account deficits and associated foreign borrowing that 
have persisted at least since the 1950's. Over this time, external deficits have occasionally sparked large currency slides and influenced macroeconomic policy settings.

The macroeconomic significance of current account imbalances and foreign borrowing has been debated at length in Australian policy circles, particularly after foreign indebtedness increased markedly subsequent to the float of the Australian dollar and the abolition of capital controls in 1983. Debate on this issue has centred on whether external deficits, perceived as a macroeconomic rather than trade competitiveness phenomenon, are necessarily a matter for policy concern (see Makin 2009 for related discussion). One view proposes that external deficits are simply the counterpart of capital inflow, or foreign investment broadly defined, and should actually be welcomed if the borrowing matching those deficits is put to productive use and helps expand the economy's capital stock.

In contrast, Australian policymakers have at times interpreted external deficits and foreign borrowing as a potential macroeconomic threat and accordingly deployed monetary and fiscal policy to reduce their magnitude. For instance, in the early 1990's official concern about the size of the current account deficit and foreign borrowing led to a sharp rise in official interest rates which lead to a policy-induced recession. For the most part however, Australia's monetary policy has targeted domestic inflation rather than the external accounts.

Meanwhile, throughout the late 1980s and up until the global financial crisis fiscal policy, especially has aimed to raise national saving via budget surpluses to alleviate the economy's call on foreign saving, although at times of domestic recession, such as the early 1980s, early 1990s and in response to the global financial crisis of 2007-08, fiscal policy has been deliberately expansionary. The general government sector in Australia comprises federal, state and local governments, although the federal government accounts for the bulk of public spending and revenue raising (Australian Treasury 2011 elaborates). 
On several occasions over recent decades, the Australian government has tightened fiscal policy on the implicit understanding that a change in the fiscal stance will reduce the external imbalance, other things the same. Yet while the macroeconomic significance of persistent current account deficits has featured prominently in Australian economic policy debate over recent decades, somewhat surprisingly there has been little research focused on the empirical relationship between this large debtor economy's consolidated fiscal imbalance and its external account imbalance.

In the next section we propose a straightforward framework for interpreting the nature of the relationship between the budget imbalance, the private saving- investment imbalance, and the external account deficit, within a relatively short analytical time frame. We then empirically estimate the influence of Australia's budget imbalance, consolidated for all levels of government, federal, state and local, on the external account imbalance using quarterly national accounts data and the latest time series methods. This estimation reveals the novel result that Australia's budget and external account imbalances are actually closely enough related to be regarded as twins. The final section concludes the paper.

\section{Fiscal and External Imbalances}

First consider the relationship between the consolidated fiscal imbalance, private saving, investment, and the external deficit. Consistent with international macroeconomic and flow of funds accounting principles set out in the System of National Accounts (United Nations 2009), we start with the basic national accounting identity,

$$
C_{p}+I+G+N X=G D P
$$

where $\mathrm{C}$ is private consumption, $\mathrm{G}$ is government spending, $\mathrm{NX}$ is exports less imports, and GDP is a given level of national production, subtract net income paid abroad, $\mathrm{y}^{*}$, from both sides of this identity and note that the current account balance,

$$
\mathrm{CAB}=\mathrm{NX}-\mathrm{y}^{*}
$$


while national income,

$$
\mathrm{Y}=\mathrm{GDP}-\mathrm{y}^{*}
$$

Substituting (2) and (3) into (1) and re-arranging yields

$$
\mathrm{CAB}=\mathrm{Y}-\mathrm{C}-\mathrm{G}-\mathrm{I} .
$$

By adding and subtracting income tax revenue, T, from the RHS of (4), and noting that net foreign borrowing $\mathrm{B}^{*}$, or capital inflow, matches the $\mathrm{CAB}$ with opposite sign $e x$ post, $\left(\mathrm{B}^{*}\right)$, under a floating exchange rate, it follows that

$$
B^{*}=I-\left(Y-C_{p}-T\right)+(T-G)=(I-S)-B B
$$

where $\mathrm{S}$ is here defined as private saving, and the consolidated budget balance, $\mathrm{BB}$, as $\mathrm{T}-\mathrm{G}$.

This simply suggests that the economy's external deficit and foreign borrowing requirement will rise when either the consolidated budget balance falls, or when domestic investment exceeds domestic private saving. In other words, this expression shows that the external deficit can vary due either to fluctuations in the consolidated budget balance or fluctuations in investment relative to domestic saving, or both.

The international macroeconomic implications of relationship (5) may be illustrated with reference to Figure 1 below which extends an approach suggested in Makin (2003). This framework differs from the standard international loanable funds framework in real interest rate - loanable funds space found in some textbooks (see Mankiw 2012 for example). Its novelty stems from its use of external imbalance - national income space to re-interpret the macroeconomic relationship between the fiscal and external deficits. It also depicts private saving, private investment and the consolidated budget imbalance for a given national income level, $\mathrm{Y}_{0}$.

The sum of private saving and public saving is drawn upward sloping since private saving is deemed to be positively related to national income, consistent with standard 
Keynesian and neoclassical theories of consumption. Investment may also be positively related without affecting the analysis, though is drawn as a horizontal schedule in the standard way.

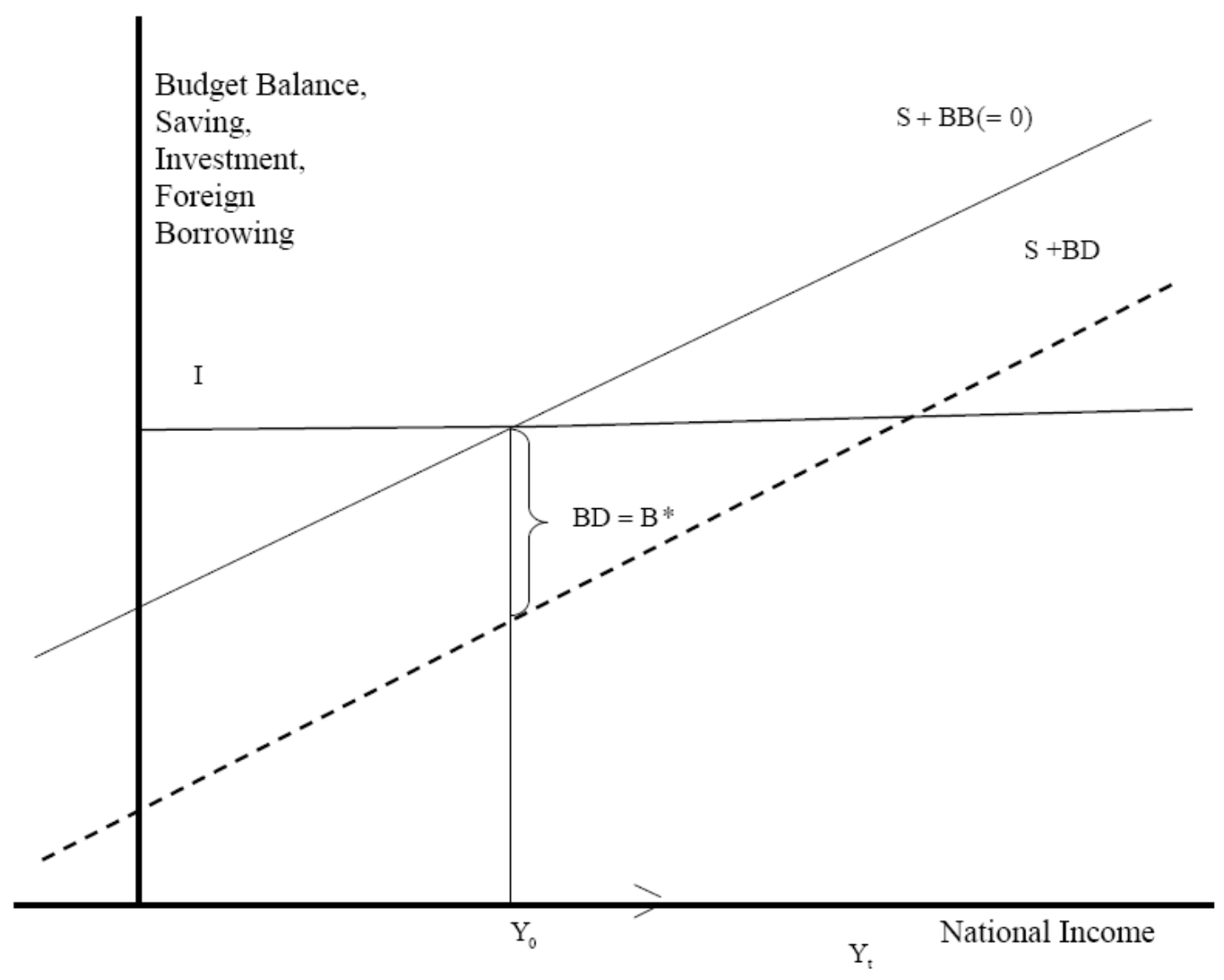

Figure 1 Budget Imbalances and Foreign Borrowing

Now assume that at an initial level of national income of $\mathrm{Y}_{0}$, the budget is balanced, $(\mathrm{BB}=0)$, and the investment and total saving schedules intersect. With the fiscal and external accounts both in balance, there is no external deficit or increased foreign borrowing requirement at that point. However, an increase in the budget deficit will immediately reduce public saving and hence total saving, other things the same, which raises the public sector and foreign borrowing requirement. According to Figure 1, for given national income, the budget deficit immediately and equivalently increases the external deficit and foreign borrowing requirement, as indicated by $\mathrm{BD}=\mathrm{B} *$. 


\section{Econometric Results}

The primary goal of this paper is to examine the relationship between the budget deficit and the foreign borrowing requirement, as conveyed in Equation (5). However, this equation is an accounting identity, a form that precludes empirical estimation of the relationship between the budget deficit and foreign borrowing. In order to derive an estimable form of equation (5), we modify it by simply using the real exchange rate as a proxy for the private savings-investment balance, on the grounds that an appreciation in the real exchange rate, a worsening of competitiveness, lowers exports, and increases imports of goods and services. Hence, an appreciation of the real exchange rate widens the trade deficit and the current account deficit, and so too the private saving-investment imbalance. This implies that real exchange rate appreciation should be positively related to the foreign borrowing requirement.

\subsection{Descriptive Statistics}

We use quarterly data from 1983Q1-2009Q1. The foreign borrowing series is sourced from Australian Bureau of Statistics, Balance of Payments and International Investment Position, Australia, Catalogue 5302, Table 1, the consolidated budget imbalance data from Australian Bureau of Statistics, Australian National Accounts, Catalogue Cat 5206, Table 15, and the quarterly real trade weighted exchange rate series from the Reserve Bank of Australia statistics database available at http://www.rba.gov.au/.

In this section, we provide some basic stylised facts about our dataset, which as explained earlier, is measured as a percentage of GDP. We begin with the plot of the three data series in Figure 1, and observe the following. First, we notice that Australia's foreign borrowing or equivalently foreign lending to Australia increased over the period 19602008. At the same time, we notice that fiscal deficits for most years have been in deficits, although in recent times Australia has experienced fiscal surpluses. On the whole, as can be seen from Table 1, the average fiscal deficit over the 49 year period was around 0.27 per cent of GDP. 
Figure 1 A plot of the data series

FL
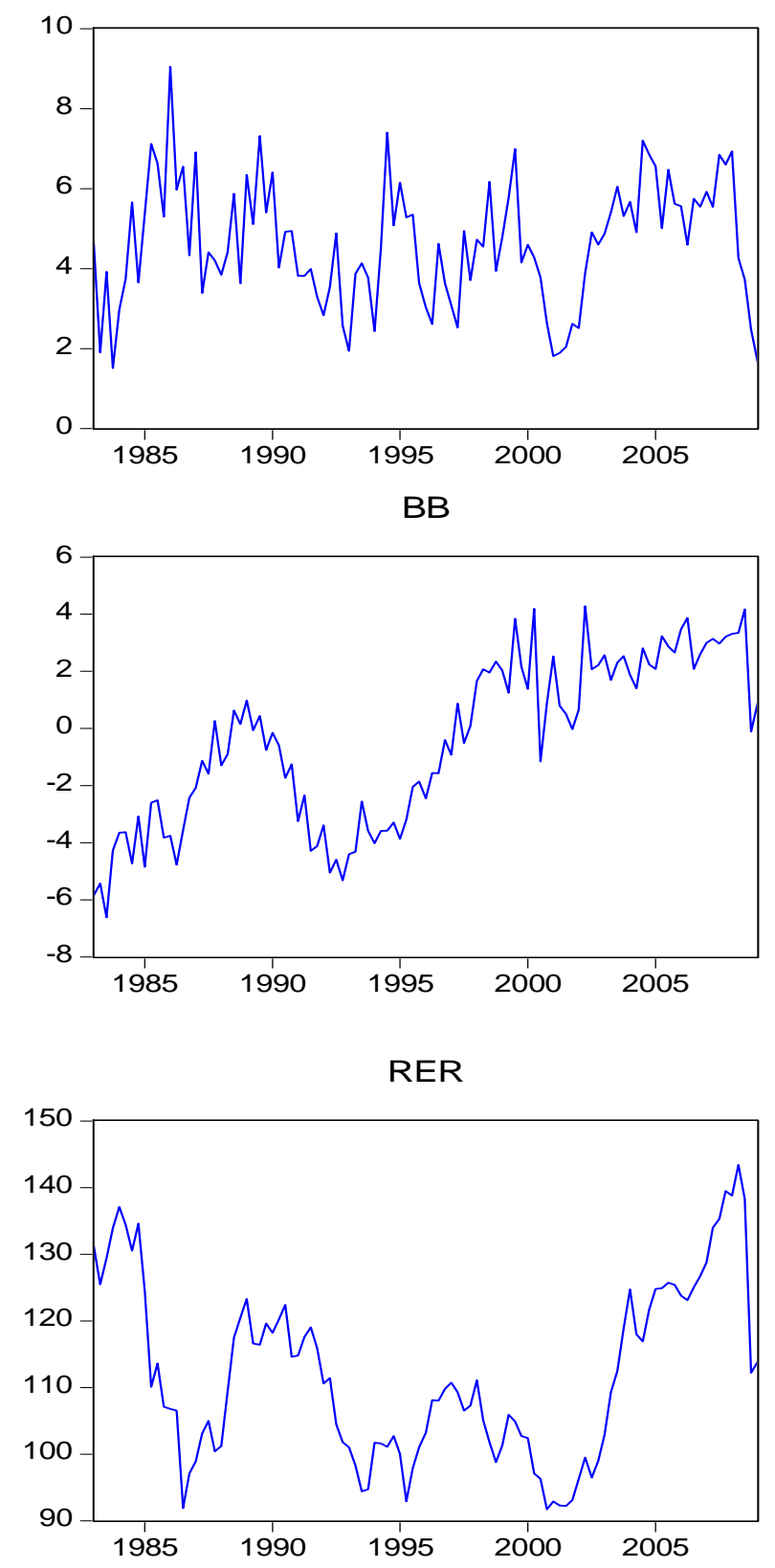

Source: These figures are generated using the EVIEWS software. 
Second, we notice that the fiscal deficit and the private investment-savings imbalances have fluctuated around the 1980s and 1990s period. From the statistics on standard deviation presented in Table 1, it is clear that the volatility of investment-savings imbalances and fiscal deficits are relatively high compared with foreign borrowing.

Table 1 Selected descriptive statistics

\begin{tabular}{llll}
\hline Statistics & Foreign borrowing & Fiscal deficit & Exchange rate \\
\hline Mean & 4.6264 & -0.5129 & 111.96 \\
Median & 4.6000 & -0.1500 & 109.80 \\
Maximum & 9.0500 & 4.2800 & 143.40 \\
Minimum & 1.5100 & -6.6100 & 91.700 \\
Standard deviation & 1.5262 & 2.8738 & 13.180 \\
\hline
\end{tabular}

Note: The descriptive statistics are generated using the EVIEWS software.

\subsection{Unit root tests}

When we examine the plots of the data series, evidence of structural changes were obvious. In this section, we search for the integrational properties of the data seriesnamely the foreign borrowing, fiscal deficit, and real exchange rate for the period 19832009. To account for structural changes when testing for unit roots is an important area of development in applied econometrics. A number of tests have been suggested that allow for mostly one and two structural breaks. Accounting for structural changes in macroeconomic time series data in testing for the unit root null hypothesis has become popular given finite sample sizes, which in most cases amounts to about 50 years of annual data. Our empirical exercise in terms of data falls in this category. Hence, it is fitting to use a two break test for the unit root null hypothesis.

On this front our work is innovative in that we use the most recent development in this field - namely the Narayan and Popp (NP, 2009) two-break unit root tests. NP consider two different models: a model that allows for two breaks in the level (which they call M1) and the other model that allows for two breaks in both the level and slope (which 
they call M2). We use the same terminology here for the sake of consistency. We consider slope breaks to be relevant because several studies, and in particular Narayan and Smyth (2006) for Australia, show that slope breaks are significant. In fact, our simple plot of the data series in Figure 1 also reflects the relevance of slope breaks.

The results are reported in Table 2. For each of the variables, the results from M1 and M2 are reported. In particular, we report the t-test statistics used to test the unit root null hypothesis, the optimal lag length, and the date of the two breaks. Panel A consists of results from M1 and panel B consists of results from M2.

Given the 5 per cent critical value of -4.5 for the M1, we are unable to reject the unit root null hypothesis for anyone of the three series, implying that foreign lending, fiscal deficit, and real exchange rate are all integrated of order one. The results from M2 corroborate those from M1: the 5 per cent critical value for the M2 is -5.2 , while all the obtained t-test statistics are greater than the critical value, implying that we cannot reject the unit root null hypothesis.

Table 2 Results from the structural break unit root test

\begin{tabular}{llll}
\hline Panel A: M1 results & Foreign borrowing & Fiscal deficit & Real exchange rate \\
\hline t-statistic & -2.8796 & -2.1133 & -2.3097 \\
Lag length & 5 & 2 & 2 \\
First break & $1986 \mathrm{Q} 2$ & $2002 \mathrm{Q} 1$ & $1990 \mathrm{Q} 1$ \\
Second break & $2005 \mathrm{Q} 4$ & $2005 \mathrm{Q} 4$ & $1991 \mathrm{Q} 3$ \\
\hline Panel B: M2 results & Foreign borrowing & Fiscal deficit & Real exchange rate \\
\hline t-statistic & -2.8099 & -1.2119 & -2.6331 \\
Lag length & 5 & 2 & 2 \\
First break & $1986 \mathrm{Q} 2$ & $1988 \mathrm{Q} 3$ & $1990 \mathrm{Q} 1$ \\
Second break & $2005 \mathrm{Q} 4$ & $2005 \mathrm{Q} 3$ & $1991 \mathrm{Q} 3$ \\
\hline
\end{tabular}

Note: The 5 per cent critical value for the M1 is -4.514 and for M2 it is -5.181 (Narayan and Popp, 2009: Table 3). The results are generated using GAUSS8.0 software; the codes were obtained from Narayan. 
That foreign borrowing, fiscal deficit, and the real exchange rate are characterised by a unit root process paves the way for testing for any possible long-run (or cointegration) relationship among the variables. This is performed in the next section using the Gregory and Hansen (1996) and the Hatemi-J (2008) tests for one and two structural break cointegration tests.

\subsection{Cointegration test}

Gregory and Hansen (1996) developed a residual based test for cointegration which takes into account one structural break. This test was extended by Hatemi-J (2008) to a case of two structural breaks. In this section, we apply both this one and two break tests to examine whether foreign borrowing, fiscal deficit, and private investment- savings imbalances are cointegrated. Their model that considers a regime shift has the following form:

$$
y_{t}=\alpha_{1}+\alpha_{2} D_{t}^{\tau}+\beta_{0} t+\beta_{1}^{\tau} x_{t}+\beta_{2}^{\tau} x_{t} D_{t}^{\tau}+\mu_{t} \quad \mathrm{t}=1, \ldots, \text { n. (7) }
$$

Here, $\alpha_{1}$ is the intercept before the shift and $\alpha_{2}$ is the change in the intercept due to the shift, $\beta_{1}$ denotes the cointegrating slope coefficients before the regime shift, and $\beta_{2}$ denotes the change in the slope coefficient. Here $D_{t}^{\tau}=0$ for $t<\tau$ and $D_{t}^{\tau}=1$ for $t \geq \tau$. To test for cointegration between $y_{t}$ and $x_{t}$ with structural change, i.e. the stationarity of $\mu_{t}$, Gregory and Hansen (1996) propose a suite of tests. These statistics are the commonly used ADF statistic and extensions of the $Z_{\alpha}$ and $Z_{t}$ test statistics of Phillips (1987). These statistics are defined as:

$$
\begin{aligned}
& A D F^{*}=\inf _{\tau \varepsilon T} A D F(\tau) \\
& Z_{\alpha}^{*}=\inf _{\tau \varepsilon T} Z_{\alpha}(\tau) \\
& \mathrm{Z}_{\mathrm{t}}^{*}=\inf _{\tau \varepsilon \mathrm{T}} \mathrm{Z}_{\mathrm{t}}(\tau)
\end{aligned}
$$


An essential part of this test is that is requires a trimming region. Consistent with the literature on small sample sizes, we use a 15 per cent trimming region. The null hypothesis of no cointegration is tested based on Equations 8-10. The critical values for the one-break test are reported in Gregory and Hansen (1996) while the critical values for the two break test are reported in Hatemi-J (2008).

The results are reported in Table 3. We find clear statistical evidence of cointegration between the three variables. Based on the Gregory and Hansen (1996) one break test, the null hypothesis of 'no cointegration' is rejected by two of the three test statistics, while based on the Hatemi-J two-break test, all the three tests reject the null hypothesis at the 5 per cent level providing stronger evidence of cointegration. The break dates are generally consistent with dates found in earlier studies using time series data on Australia.

We find break dates in the mid-1980s and early 1990s. The latest break seems to have occurred in early 2001. Narayan and Smyth (2005) argue that the mid-1980s break coincides with significant structural reforms, which included abolition of exchange rate controls and financial deregulation, while the early 1990s break coincides with the onset of the inflation targeting policy. With respect to the 2001 break, this coincides with a global recession in that year, during which there was major capital outflow causing the Australian dollar to fall to its lowest point ever against the \$US.

Table 3 Gregory and Hansen test

\begin{tabular}{lllllll}
\hline FB=f(BB, RER) & ADF & $\mathrm{T}_{\mathrm{b}}$ & $\mathrm{Z}_{\mathrm{t}}^{*}$ & $\mathrm{~T}_{\mathrm{b}}$ & $\mathrm{Z}_{\alpha}{ }^{*}$ & $\mathrm{~T}_{\mathrm{b}}$ \\
\hline One-break & $-5.029[1]$ & $1991 \mathrm{Q} 1$ & $-6.989^{* *}$ & $1986 \mathrm{Q} 4$ & $-67.89^{* *}$ & $1986 \mathrm{Q} 4$ \\
Two-break & $-5.861^{* *}[1]$ & $1991 \mathrm{Q} 4$ & $-7.295^{* *}$ & $1986 \mathrm{Q} 4$ & $-92.842^{* *}$ & $1986 \mathrm{Q} 4$ \\
& & & & & $2001 \mathrm{Q} 2$
\end{tabular}

Notes: For the one-break test, the $5 \% \mathrm{CVs}$ are -5.50 and -58.33 for the $\mathrm{ADF} / \mathrm{Z}_{\mathrm{t}}^{*}$ tests and $\mathrm{Z}_{\alpha}{ }^{*}$ tests, respectively (Gregory and Hansen, 1996). For the 2-break test, the corresponding 5 per cent CVs are -6.46 and -83.64 (Hatemi-J, 2008). The results are generated using the GAUSS8.0 software. The codes were obtained from Hansen's webpage for the one-break test and from Hatemi-J for the two-break test. 


\subsection{Long-run Elasticities}

The long-run elasticities of the impact of budget deficit and fiscal imbalances on foreign lending are reported in Table 4. The results are based on three different estimatorsnamely the ordinary least squares (OLS), the dynamic OLS, and the fully modified OLS. The results are robust and consistent across all estimators. Generally the results are consistent with theoretical expectations in that as budget deficits increases, it leads to a rise in foreign borrowing. The real exchange rate has been used as a proxy for the private saving-investment imbalance and the results here are also consistent with our a priori reasoning that an appreciating real exchange rate should raise foreign borrowing because this worsens international competitiveness and hence the current account deficit.

Table 4 Long-run elasticities

\begin{tabular}{lll}
\hline & Budget deficit (BB) & Real exchange rate (RER) \\
\hline OLS & $0.1036^{* *}(0.0438)$ & $0.0223^{* *}(0.0464)$ \\
DOLS & $0.0914^{*}(0.0714)$ & $0.0276^{* * *}(0.0091)$ \\
FMOLS & $0.1085^{*}(0.0840)$ & $0.0239^{*}(0.0780)$ \\
\hline
\end{tabular}

Notes: *** denote statistical significance at the 1 per cent level and probability values are in parenthesis. The results are generated using the GAUSS8.0 software.

We also estimate the short-run elasticities based on the error correction model proposed by Engle and Granger (1987). We obtain a coefficient of 0.067 on budget deficit and 0.003 on real exchange rate. Both variables, however, are statistically insignificant. The one-period lagged error correction term, which captures the speed of adjustment to equilibrium following a shock to the system, as expected, turns out to be negative and statistically significant. Its coefficient is 0.51 and it is statistically significant at the 1 per cent level.

\subsection{Structural stability test}

In this section, we aim to test for any structural break dates in our trimmed sample period, based on Equation (7). To achieve this goal, we use the Quandt-Andrews test. This test 
examines one or more structural break points in a sample. The null hypothesis is "no breakpoints", and the test statistics are based on the Maximum statistic, the Exp Statistic, and the Ave statistic (see Andrews, 1993; and Andrews and Ploberger, 1994). We choose a trimming region of 15 per cent. The probability values are calculated using Hansen's (1997) method and automatically computed in the EVIEWS software. The p-values that are close to one, are rounded-off to one. The results are reported in Table 5. Total breakpoints considered by the test were 83 and the null hypothesis of no break within the trimmed sample period is not rejected by any of the three test statistics.

Table 5 Quandt-Andrews unknown breakpoint test

\begin{tabular}{lll}
\hline Statistic & Value & P-value \\
\hline Max. LR F-stat. (1977) & 0.8050 & 1.000 \\
Max. Wald F-stat. (1977) & 0.8050 & 1.000 \\
Exp LR F-stat. & 0.1218 & 1.000 \\
Exp Wald F-stat. & 0.1218 & 1.000 \\
Ave LR F-stat. & 0.2332 & 1.000 \\
Ave Wald F-stat. & 0.2332 & 1.000 \\
\hline
\end{tabular}

Source: The results are generated using the EVIEWS software.

\section{Conclusion}

This paper contributes to the literature on fiscal-external imbalances in two ways. First, it presents a simple framework for understanding why these imbalances should be linked in principle. Second, using Australia as a case study, it estimates the impact of changes in Australia's budget imbalance on its net external borrowing using quarterly data for the period 1983-2009. This yields the novel result that Australia's fiscal-external imbalances are closely enough related on the basis of quarterly data to pass as twins, a finding which contrasts markedly with previous studies examining this issue for the United States, and groups of industrial and emerging economies using pooled estimation techniques. 
Nonetheless, these results do not necessarily suggest a close relationship would hold as strongly when examining periods longer than a quarter, such as on an annual basis. Over longer periods, other macroeconomic variables, such as private saving, are likely to respond to altered fiscal activity for a range of reasons. These include offsetting private saving behaviour by households, perhaps on a partial basis, to meet future taxes that higher public debt implies, as proposed by the Ricardian equivalence proposition (Barro 1989, Ricciutti 2003, and Seater 1993).

The internationally co-ordinated fiscal response of Group of 20 economies to the Global Financial Crisis of 2008-09 restored fiscal activism and the significance budget deficits to the forefront of macroeconomic analysis and policy. Yet the extant literature on using fiscal policy to influence national income and employment, as surveyed recently for instance by Auerbach et al (2010), mostly presumes economies are closed to international economic influences and hence largely neglects the links between budget and current account imbalances highlighted in this paper.

The relationship between any open economy's budget imbalance and its external account imbalance has major implications for macroeconomic policy management. For instance, the stronger this relationship is in the short run, the less impact fiscal stimulus has on the domestic economy due to spending leakage abroad. In other words, the more fiscal deficits dissipate through external deficits reflecting higher imports and lower exports, the weaker is any fiscal multiplier. In the limit case of a short run one-for-one relationship between the fiscal deficit and the external deficit, fiscal stimulus is not likely to have any net impact on domestic GDP and employment. Our paper suggests this has been so for Australia.

Such a finding is fully consistent with the predictions of the Mundell (1963) - Fleming (1962) model of an open economy that, even during recessions, fiscal stimulus in an open economy is ineffective in raising aggregate demand with a floating exchange rate and highly mobile international capital because it 'crowds out' net exports. As conveyed in the earlier Figure 1, it is also consistent with international macroeconomic accounting 
and flow of funds precepts which imply that, other things equal, a rise (fall) in an economy's fiscal deficit should be fully matched by a rise (fall) in its net foreign borrowing.

In addition, fiscal deficits that directly raise external liabilities in the form of public debt owed to foreign interests can threaten an economy's creditworthiness and thereby increase its vulnerability to sudden capital flow reversals and financial crises, which have immediate effects on real interest rates, national income and employment levels. Furthermore, over the medium term higher interest servicing costs on an escalating stock of foreign debt will reduce national income, other things the same. 


\section{References}

Andrews, D. (1993) Tests for parameter instability and structural change with unknown change point, Econometrica, 61, 821-856.

Andrews, D. and Ploberger, W., (1994) Optimal tests when a nuisance parameter is present only under the alternative, Econometrica, 62, 1383-1414.

Auerbach, A., Gale, W. and Harris, B. (2010) “Activist fiscal policy” Journal of Economic Perspectives 24(4), 141-164.

Australian Bureau of Statistics, Australian National Accounts, Catalogue No. 5206, Australian Government Printing Service, Canberra.

Australian Bureau of Statistics, Balance of Payments and International Investment Position, Australia, Catalogue No. 5302, Australian Government Printing Service, Canberra.

Australian Treasury, (2011) Commonwealth Budget 2011-12, Australian Government Printing Service, Canberra.

Barro, R. (1974) Are government bonds net wealth? Journal of Political Economy, 81, 1095-1117.

Chinn, M. and Prasad, E. (2003) Medium term determinants of current accounts in industrial and developing countries: an empirical exploration, Journal of International Economics 59, 47-76.

Corsetti, G and Muller, G. (2006) Twin deficits: squaring theory, evidence and common sense" Economic Policy, 48, 597-638.

Dibooglu, S. (1997) Accounting for US current account deficits: an empirical investigation, Applied Economics 29 (6), 787-793.

Engle, R.F., and Granger, C.W.J., (1987) Co-integration and error correction: representation, estimation and testing, Econometrica, 55, 251-276.

Fleming, J. (1962) Domestic financial policy under fixed and floating exchange rates. IMF Staff Papers, 9(3), 369-79. 
Gregory, A. and Hansen, B. (1996) Residual based tests for cointegration in models with regime shifts, Journal of Econometrics, 70, 99-126.

Hatemi-J A., (2008) Tests for cointegration with two unknown regime shifts with an application to the financial market integration, Empirical Economics, 35, 497-505.

Hansen, B., (1992) Tests for parameter instability in regressions with I(1) processes, Journal of Business and Economics Statistics, 10, 321-335.

Hansen, B. (1997) Approximate asymptotic p-values for structural-change tests, Journal of Business and Economic Statistics, 15, 60-67.

International Monetary Fund (2011) World Economic Outlook, September, IMF, Washington DC.

Kim, S. and Roubini, N. (2008) Twin deficits or twin divergence? Fiscal policy, current account, and real exchange rate in the US Journal of International Economics, 74, 362-383.

Kraay, A. and Ventura, J. (2000) Current accounts in debtor and creditor countries, Quarterly Journal of Economics 115, 1137-1166.

Makin, A. (2009) Global Imbalances, Exchange Rates, and Stabilization Policy, Palgrave Macmillan, Basingstoke.

Makin, A. (2004) The Current Account, Fiscal Policy and Medium Run Income Determination Contemporary Economic Policy (22), 309-317.

Makin, A. (2003) Global Finance and the Macroeconomy, Palgrave Macmillan, Basingstoke.

Mankiw, G. (2012) Macroeconomics, $8^{\text {th }}$ ed, Worth, New York.

Masson, P. Bayoumi, T. Samiei, H. (1998) International evidence on the determinants of private saving, World Bank Economic Review 12: 483 - 501.

Mundell, R. (1963) Capital mobility and stabilization policy under fixed and flexible exchange rates, Canadian Journal of Economics and Political Science, 29 (4), 475-85. 
Narayan, P. and Popp, S. (2009) A new unit root test with two structural breaks in level and slope at unknown time, Journal of Applied Statistics, 37(9), 1425-1438.

Narayan, P., and Smyth, R. (2005) Structural breaks and unit roots in Australian macroeconomic time series, Pacific Economic Review, 10, 421-437.

Nason, J. and Rogers, J. (2002) Investment and the current account in the short run and the long run,

Journal of Money, Credit and Banking, 34.

Normandin, M. (1999) Budget deficit persistence and the twin deficits hypothesis, Journal of International Economics, 49, 171-193.

Ricciutti, R. (2003 Assessing Ricardian equivalence, Journal of Economic Surveys 17 (1), 55-78.

Seater, J. (1993) Ricardian equivalence, Journal of Economic Literature, 31(1), 142-90.

United Nations (2009) System of National Accounts, 2008, United Nations, New York. 